\title{
Commercial Biological Control Agents Targeted Against Plant-Parasitic Root-knot Nematodes
}

\author{
Marie-Stéphane Tranier ${ }^{1 *}$, Johan Pognant-Gros ${ }^{1}$, Reynaldo De la Cruz Quiroz $^{2}$, Cristóbal \\ Noé Aguilar González ${ }^{2}$, Thierry Mateille ${ }^{3}$ and Sevastianos Roussos ${ }^{1}$ \\ ${ }^{1}$ Institut Méditerranéen de Biodiversité et d'Ecologie marine et continentale (IMBE); UMR CNRS IRD; Aix Marseille \\ Université; Marseille - France. ${ }^{2}$ Departamento de Investigación en Alimentos; Universidad Autónoma de Coahuila; \\ Saltillo - México. ${ }^{3}$ Centre de Biologie pour la Gestion des Populations (CBGP); IRD; Montferrier sur Lez Cedex - France
}

\begin{abstract}
Root-knot nematodes are microscopic round worms, which cause severe agricultural losses. Their attacks affect the productivity by reducing the amount and the caliber of the fruits. Chemical control is widely used, but biological control appears to be a better solution, mainly using microorganisms to reduce the quantity of pests infecting crops. Biological control is developing gradually, and with time, more products are being marketed worldwide. They can be formulated with bacteria, viruses or with filamentous fungi, which can destroy and feed on phytoparasitic nematodes. To be used by the farmers, biopesticides must be legalized by the states, which has led to the establishment of a legal framework for their use, devised by various governmental organizations.
\end{abstract}

Key words: Biopesticides, Meloidogyne spp., Filamentous Fungi, Homologation, Production, Formulation

\section{INTRODUCTION}

Root-knot nematodes are disease-causative agents, well-known by farmers, for example, tomato producers in Morocco. Each year, these microscopic worms cause considerable losses. Biopesticides may be a good solution to reduce the damages, but they have to be legalized by the governments. Filamentous fungi may play a good role in the control of this pest, using different action pathways. They have to be formulated to preserve their viability and virulence against the nematodes, and then to be approved for use on the crops by farmers.

\section{ROOT-KNOT NEMATODES (RKN)}

Nematodes are classified under the Nematoda Phylum, which forms part of the Ecdysozoa superphylum, from the Greek ecdysis (moulting) and zoo (animal). They possess a cuticle and must moult to continue their development (Bélair 2005). Most of them are said "free" and feed essentially on bacteria, fungi, protozoa and other nematodes, and only a minority parasites animals and plants (Bélair 2005).

Meloidogyne spp. or RKN are round worms (Brand et al. 2009) belonging to Tylenchida family. They are cylindrical and thread-like triploblastic Metazoans that show bilateral symmetry, a thick cuticle, and non-ciliated, nonsegmented teguments (Grassé et al. 1965). They were discovered during the $14^{\text {th }}$ century as phytoparasites of intertropical and warm climate cultures. The agricultural losses they cause, in particular in greenhouse cultures of tomatoes in the Souss-Maasra Drâa region in Morocco, are considerable. Worldwide, more than USD 125 billions/year are lost due to nematodes, most of

*Author for correspondence: marie.tranier@imbe.fr 
them due to RKN (Koenning et al. 1999; Chitwood 2003; Collange et al. 2011; Bissadou et al. 2012). The degree of these damages can be even more severe as nematodes can increase susceptibility to other parasites (Bridge et al. 2005).

The Meloidogyne genus subdivides in different species, all phytophagous, with $M$. arenaria, $M$. incognita, $M$. hapla and $M$. javanica being commonly widespread (Netscher 1970; Sawadogo et al. 2000; Hunt and Handoo 2009). The number of plants susceptible to Meloidogyne spp. is very high (more than 2,000 species, a constantly increasing figure), and includes tobacco (Nicotiana tabacum), coffee (Coffea arabica), tomato (Solanum lycopersicum), Niebe (Vigna sinensis), Kenaf (Hibiscus cannabinus L.), sugar cane (Saccharum officinarum), tea (Camellia sinensi), carrot (Daucus carota), melon (Cucumis melo), etc. Meloidogyne spp are round worms, 0.4 to $1.0 \mathrm{~mm}$ long and $0.25-0.75 \mu \mathrm{m}$ in diameter for the females and $1.2-1.5 \mathrm{~mm}$ long and $30-36 \mu \mathrm{m}$ in diameter for the males (Agrios 1997). These present a stylet, which is used to pierce the cell walls of the roots of the host plants (Davis et al. 2000). As they enter the root, the larvae will provoke a cortical cell hypertrophy due to the excretion of secretions through the stylet. Multinucleated "giant cells" are thereby formed (Bird 1962), which cause the formation of gall, which is characteristic of the attack by a Meloidogyne spp.
Once hatched, J2 free larvae become obligatory parasites that have to continue their cycle into adult stage in host-plant roots only (Sharon et al. 2001). For that purpose, they swim into the water pellicle surrounding the soil particles. Once they penetrate the root thanks to the stylet, the larvae move both in and between the cells. They move to the central cylinder along which they immobilize (Fig. 1A). At this time, L3 and L4 larvae turn into sexual adults, presenting strong dimorphism (Fig. 1B): males stay vermiform whereas females become pyriform and sedentary, their heads lodged in giant cells. Once fecundated, females lay eggs (around 500/mass) agglomerated at all the stages of development in a gelatinous substance, from the unicellular stage to the ready-to-hatch stage. Egg development between these two stages could take from seven to nine days at $28^{\circ} \mathrm{C}$. During this time, nematodes undergo a first molting and the larvae that hatch are $\mathrm{J} 2$ secondstage larvae (De Guiran and Netscher 1970).

A higher temperature may accelerate the cycle; yet temperatures above $40^{\circ} \mathrm{C}$ are lethal. Eggs are the nematodes' resistant form, so they survive unfavorable conditions of life. In the absence of males, females are also able to produce fertile eggs in a parthenogenetic way (Agrios 1997). Typical symptoms of damage caused by the nematodes are a reduction of the root system, root structure distortion or root diameter increase, and gall presence. Plants turn yellow and wither and a production decrease is observed (Agrios 1997).
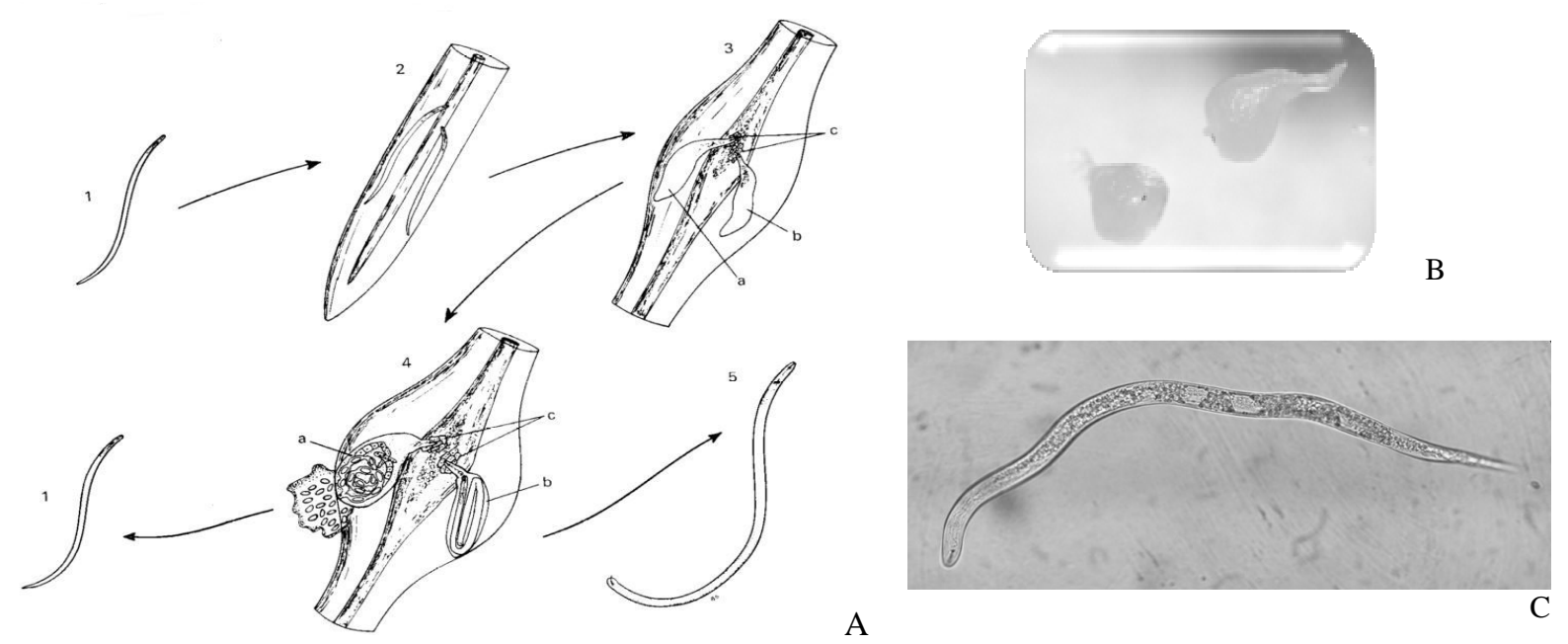

Figure 1 - A. Schematized cycle of Meloidogyne spp. - 1. Free second stage larva; 2. Second stage larva penetrating a growing root; 3. Root in formation : a-b : Swolled second stage larva ; $\mathrm{c}$ : Giant cells ; 4 . Gall containing : a : adult female which had laid her eggs in the gelatinous substance ; $\mathrm{b}:$ adult male curled up in the larval envelopes ; c : Giant cells; 5. Free adult male (By De Guiran G. and Netscher C. 1970) ; B. Photo of females of M. javanica (M. Tranier) and C. J2 larvae of M. javanica (M. Tranier). 


\section{BIOLOGICAL CONTROL}

\section{General Definition}

Founded in 1956, the International Organization of Biological Control (Iobc 2014) is set to promote environmentally-, socially- and-economicallyefficient methods to eliminate the diseases and pests from agriculture and forests. It defines biological control as «the use of living organisms or their products to eliminate or reduce the damages or losses due to pests ». Biological control involves the use of beneficial organisms, of their genes and/or of products such as metabolites that reduce the negative effects of plant pathogens and promote positive responses from the plant (Junaid et al. 2013). More precisely, it uses living populations of parasitoid, predatory, pathogenic, antagonist or competing organisms to reduce a pest population, making it less abundant and less harmful than it would otherwise have been (De Bach 1964; Stirling 1991; Siddiqui and Mahmood 1996). The Biological Control Agent (BCA) is then the organism or its product which combats the pest. It is usually called a «biopesticide».

Biopesticides are generally defined as the "products aimed at protecting the plants, made from living organisms or natural substances from species co-evolution, not produced by chemistry, and the use of which is recommended for the control of pests or bio-aggressors for a better respect of the biocenosis and environment". According to this definition, Genetically Modified Organisms (GMO) that are not issued from the coevolution of species and which have known too little anteriority in terms of impact on biological communities and the environment should so far be excluded from the field of biopesticides.

If the antagonist is a microorganism, microbiological control could be considered. In general, the microorganism infects the host by ingestion and has a resistant form that permits it to pass through - and stay in - the medium (soil, foliage, litter). The pathogen multiplies in the host and causes its death by tissues destruction, septicemia, and sometimes the emission of a toxic substance (case of bacteria). Host cadavers release the pathogenic agents in the medium. When the antagonists have to be inoculated in large numbers to effectively reduce the pest, the method is called inundative biological control; it is frequently used, but poses the problem of the future of the auxiliary populations introduced in the field.
Biological control appears to be an excellent alternative to the chemical one, which is the major method used to fight the pests. It consists in a general disinfection of fields (before each plantation) with fumigants or precursors, but presents a real danger for the environment and human health. These chemical products indeed present serious drawbacks (wide action spectra, disturbed ecological balances, pollution of the environment and food-chain, insufficient results, long-term resistance of pests). This method of control also poses the problem of the necessary delay between the product's application and harvest. Moreover, widely-used chemical products (like methyl bromide) are increasingly banned, which poses the problem of the existence of alternatives, if possible within the legal framework of organic farming. However some alternatives to chemical products do exist, which are used but present limited effects: inundation and summer solarization are two examples (Van der Putten et al. 2006; Djian-Caporalino et al. 2009; Collange et al. 2011). Inundation causes anaerobic conditions that reduce the occurrence of $\mathrm{RKN}$, but it requires a long flooding period (eight weeks) to be efficient, and causes water consumption, lack of oxygen and degradation of the soil's structure, which is not suitable to agronomic practices (Collange et al. 2011). Summer solarization, in the intercropping period, consists in covering the soil with a plastic film during the hottest months of the year to increase the soil's temperature. It helps neutralize thermosensible pathogens at depths up to $20 \mathrm{~cm}$, like root-knot nematodes. However, the heat can't penetrate into the deeper layers of the soil where nematodes can also shelter. Soil amendments with composts or manures can stimulate natural microbial soil flora and have a repressive effect on phytoparasitic nematode populations (Bélair 2005). Over the last few years, biological control has, thus, been developing. This article presents a review on nematode-antagonistic fungi and some of the commercial products associated.

\section{FUNGI AS BCA AGAINST MELOIDOGYNE SPP}

Fungi naturally exist that have an antagonistic action against the nematodes in general (SarhyBagnon et al. 2000, Brand et al. 2004), more precisely Meloidogyne spp. (Viaene and Abawi, 1998a; Stirling et al. 1998; Stirling and Smith 
1998; Duponnois et al. 1998; 2001; Kumar and Singh 2006; Thakur and Devi 2007; Liu et al. 2008; Collange et al. 2011). The infection process is generally the same: cuticle penetration, immobilization, invasion and digestion of the nematode (Huang et al. 2004). The nematodes' cuticles and egg walls play an important role in the infestation by fungi. The cuticle is essentially made of proteins (chitin, collagen, fibers) and can play the role of a precursor in the invasion of the nematodes by nematophagous fungi (Huang et al. 2004). Whatever the mode of action of the fungus, predation or parasitism, the interaction between a fungus and a host organism or prey requires penetration of the outer shell of the body. This penetration occurs before the colonization of the internal structures of the body through digestion, allowing the fungus to meet its nutritional needs (Gaspard et al. 1990; Hajieghrari et al. 2008). Cayrol et al. (1992) classified the nematophagous fungi according to their mode of action against the nematodes.

\section{Predatory fungi (Cayrol et al. 1992)}

Some fungi have the ability to trap the nematodes they feed on. They differ by their trapping mode: network traps (Arthrobrotrys oligospora, A. superba), constrictive rings (A. anchonia, A. dactyloides, Dactylaria brochopaga, etc), or adhesive knobs (Monacrosporium cionopagum, Dactylella lobata). Some fungi, such as Dactylaria candida (Hyphomycete) present two types of trapping mechanism: i) adhesive knobs, and ii) constrictive but non-adhesive rings (B'Chir 1984). These fungi are saprophytes, but they can trap the nematodes in a larval or free adult stage in the soil. It has been proven that the production of peptides by extracellular proteases hydrolyzing the nematodes' cuticles may induce trap formation (Huang et al. 2004).

\section{Egg-parasitic fungi (Cayrol et al. 1992)}

These fungi have the ability to infect and destroy nematode's eggs. Most of the fungi that have this mode of action are saprophytes, and can secondarily invade already-dead eggs. Eggparasitic fungi include Paecilomyces, Pochonia and Verticilium genera. Paecilomyces lilacinus and Pochonia chlamydosporia are probably the most effective egg-parasites. P. lilacinus has been proven to successfully control root-knot nematodes, $M$. javanica and $M$. incognita on tomato, egg-plant and other vegetable crops (Cayrol et al. 1989; Verdejo-Lucas et al. 2003; Goswami and Mittal 2004; Van Damme et al. 2005; Goswami et al. 2006; Haseeb and Kumar 2006).

\section{Nematophagous fungi with adhesive spores (Cayrol et al. 1992)}

Nematodes can be parasited by the fungi with adhesive spores belonging to several classes: Oomycetes (Catenaria anguillulae, Myzocytium lenticulare, $M$. anomalum with biflagellated zoospores able to encyst in the nematode's cuticle), Zygomycetes (Meristracum asterospermum, with spherical conidia, which produce a germinative filament after adhesion that germinates and creates new conidiospores), Deuteromycetes (Meria coniospora with club-like spores, which fix on the host via their anterior part), and Basidiomycetes (Nematoctonus leiosporus, with adhesive spores) and Hyphomycetes (Hirsutella $s p$ ). Exclusively endoparasitic fungi must live their entire cycle in the host nematodes.

\section{Endomycorhizes with arbuscular vesicles (Cayrol 1992)}

Mycorhizes are fungi associated with the plant roots in a symbiotic way, presenting a double mycelial network: one external, in the soil, and one internal, in the tissues of the host-plant. The mycelial network expands widely in the rhizosphera and exploits a large volume of soil, which ensures abundant nutrition for host-roots, increasing the assimilative potential of the plant. Nematodes living in these roots compete in intraroot nutrition and face a plant becoming more resistant, thanks to the nutritional amelioration due to mycorhizes.

\section{Microbial toxins}

Some substances are naturally nematifuge (repulsives), nematostatic (perturbating host-plant reconnaissance by the nematode; blocking the development of the egg or the larva; or temporarily paralyzing the animal) or nematicide (sensus stricto: ovicide, larvicide or lethal for all stages). Some studies have been conducted, but it seemed that some enzymes produced by the fungi, or volatile organic compounds (e.g., 6-pentyl- $\alpha$ pyrone, produced by Trichoderma harzianum), could have some antagonistic effects on 
nematodes (Sarhy-Bagnon et al. 2000). It has been proven that the toxin produced by Bacillus thuringiensis is efficient in vitro (Cayrol et al. 1992)

\section{Actinomycetes against Meloidogyne}

Gram-positive parasite bacteria such as actinomycetes (e.g. Pasteuria penetrans) possess BCA qualities against phytoparasitic nematodes (Mateille 1993). Spores staying in soil adhere to the $\mathrm{J} 2$ when they pass near the colonies. Adhesion is very specific of the Meloidogyne genera and of its larval stage. Spore germination occurs eight days after the $\mathrm{J} 2$ penetrates the root and starts feeding on it. This Actinomycete is perfectly synchronized with the development and the physiology of Meloidogyne. Then, a germinative tube is formed by the cuticle and infestation occurs. At the end, Pasteuria penetrans forms new hypha and spores inside the females, which become sterile as their reproductive system is destroyed.

\section{Other organisms}

There are carnivorous predatory nematodes belonging essentially to the order of Mononchida, to the Diplogasteridae suckers family, and to the Dorylaimidae omnivorous family, and others with toxic effects (Aphelenchidae). Some insects can also be nematophagous such as Entomobryoides dissimilis or nematodes' predatory mites (Alliphis spp., Alicorhagia spp.). But if the predation of these organisms is indisputable, their effects on nematode populations are unknown.

\section{MAIN AGENCIES FOR THE HOMOLOGATION OF BCA'S, AND THEIR MARKET}

Biocontrol agents and biopesticides must undergo an approval process before being placed on the market. This is a long and costly process but makes sure that the product brought to the field is both safe for humans and the environment. There are government organizations (agencies) responsible for defining the rules for using these products that come into contact with the food chain.

\section{THE ENVIRONMENTAL PROTECTION AGENCY (EPA)}

This U.S. government agency (United States 2014) is responsible for assessing the risks of the products used in the crops for food. Its mission is to protect both human health and the environment. When the Congress passes an environmental law, the EPA writes the regulations that strengthen it. This is the organization that certifies "biopesticide" products in the U.S., a leader in the field of biopesticides. In 2008, 279 biopesticides were registered in the U.S. compared to 77 in Europe, due to a procedure which is more complex and time consuming for the latter. However, the EPA does not require testing efficiency in its reviewing process. One can thus register a biopesticide on the sole basis of its safety for human health and the environment without demonstrating its effectiveness under different conditions for which the product may have to be used (Caron et al. 2006).

\section{The Pest Management Regulatory Agency (ARLA)}

The ARLA (Santé - Canada 2014) of Canada is committed to promoting, verifying and ensuring the compliance with the Act on the label. This is equivalent to the U.S. EPA. Unlike the EPA, the ARLA requires that the pesticide potential of a product be demonstrated, and that, over several seasons and over all particular geographical areas of Canada. This requirement leads to huge additional costs for the companies, which often cause the product not to meet the market's expectation. However, authorization by ARLA can be granted on the sole basis of EPA's registration of the same product (Caron et al. 2006).

\section{The French Ministry of Agriculture and Fishing}

It is responsible for assigning the AMM (Marketing Authorization) after assessing the risks of the product under investigation. For this, it relies on the Office of Pesticides and Fertilizers. Risk assessment is carried out by a committee of experts. The work of the experts and of the Commission for the Study of Toxicity is coordinated by the SSM (Joint Scientific Structure). The Accreditation Committee then makes a proposal, based on risk and efficiency assessments. The AMM, preceded by a provisional marketing authorization, is issued by the State and is valid throughout the European territory (France 2014). 


\section{The Organic Materials Review Institute (OMRI)}

Founded in 1997, the Organic Materials Review Institute (OMRI) is a nonprofit organization (Omri 2014), which provides organic certifiers, growers, manufacturers, and suppliers an independent review of products intended for use in certified organic production, handling, and processing. When companies apply, OMRI reviews their products against the National Organic Standards. Acceptable products are OMRI-listed $\AA$ and appear on the OMRI Products List. OMRI also provides subscribers and certifiers guidance on the acceptability of various material inputs, in general under the National Organic Program.

\section{The market for Biological Control Agents}

The global pesticide market is constantly changing and was estimated at USD 43 billion in 2009, with predictions for an annual increase of 5 to $8 \%$ for each subsequent year. Two competitors, chemical pesticides and biopesticides, share this market. With recent developments in global market requirements for pesticide residues, and the desire for products from organic agriculture, biopesticides have gained much attention. Exponential growth is predicted in this sector, which currently accounts for USD 1.6 billion. The United States are a leader in this area but the most important market growth for biopesticides is in Europe. The market in Europe was USD 270 million in 2010 and a $15 \%$ increase was expected in this sector. France ranked third on this market, behind Spain and Italy (Source: Europe: Pesticides Biomarket, CPL Consultants 2010). In Europe, several companies compete in this market: Novartis (18.4\%), Koppert (18.2\%), Abbot Laboratories (12.5\%), AgrEvo Intrachem, BASF, Bayer cropscience, etc.

\section{MAJOR FUNGAL PREPARATIONS ACTIVE ON MELOIDOGYNE AVAILABLE ON THE MARKET}

In the U.S., more than 279 biopesticides (all inclusive) were approved in 2009 against only 77 in France. This was due to a more restrictive policy on the part of the European Union. Fourteen bacterial and twelve fungi have been registered with the EPA for the control of plant diseases (Fravel 2005). Among the products available on the market, only a few of the best-known biological nematicides are given below.
BIO-ACT ${ }^{\circledR} /$ MELOCON WG (Prophyta 2014) Marketed by Prophyta (acquired in 2013 by Bayer CropSscience Biologics $\mathrm{GmbH}$ ), BioAct ${ }^{\circledR}$ is a biological nematicide used for biocontrol of the root-knot nematodes (Brand et al. 2009). It contains $10^{10}$ spores per dry weight gram of the ovicidal fungus, Paecilomyces lilacinus strain 251, which is a highly effective parasite of all the stages of development of common plant-infecting nematodes, especially the eggs and infectious juveniles. Formulated as a water-dispersible granule, BioAct ${ }^{\circledR} /$ MeloCon can be applied through conventional methods, using the irrigation system. Paecilomyces lilacinus is filamentous Ascomycete fungus that controls phytoparasitic nematodes such as Meloidogyne spp. (Kiewnick and Sikora 2004; Kiewnick and Sikora 2006; Khan et al. 2006; Mukhtar et al. 2013), Radopholus similis (Mendoza et al. 2007), Heterodera spp., Globodera spp. and Pratylenchus spp. Direct interactions between $P$. lilacinus strain 251 and eggs but also females of $M$. javanica were demonstrated in vitro by Holland et al. (1999).

\section{BOTANIGARD $^{\circledR}$; MYCOTROL ${ }^{\circledR}$}

In 2009, the ARLA, under the authority of the Pest Control Products Act and Regulations, made a full registration of the Technical Beauveria bassiana, named Botanigard $^{\circledR}$ ES or Botanigard ${ }^{\circledR} 22 \mathrm{WP}$ (Laverlam 2014) and Mycotrol $\mathrm{O}^{\circledR}$ or Mycotrol ES $^{\circledR}$ (Laverlam 2014), containing the B. bassiana strain GHA, a technical-grade active ingredient for sale and use in against whiteflies, aphids and thrips in vegetable and ornamental greenhouses. These products are also registered by the EPA. The $B$. bassiana GHA is found naturally in the soils throughout the world and parasitizes various insect species. It is a "generalist entomopathogenic fungus" - a fungus that causes disease in many types of insects. As the insects that live in the ground or near the ground have evolved natural defenses against $B$. bassiana because it is common in the wild, this fungus can be used as a biological insecticide against most other insects. Although its approval does not stipulate it, B. bassiana has a repressive action on nematodes of the genus Meloidogyne spp (Bradley et al. 1992; Bekanayake and Jayasundar 1994; Liu et al. 2008).

\footnotetext{
BIOSTAT $^{\circledR}$

BIOSTAT $^{\circledR}$ (EPA approved) contains a biotype of Purpureocillium lilacinum, selected for its capacity to control plant pathogenic nematodes,
} 
such as: Meloidogyne sp., Radopholus sp., Pratylenchus sp., Tylenchus sp., Ditylenchus sp., Helicotylenchus sp. and Rotylenchulus sp. It parasitizes all reproductive stages of plant pathogenic nematodes, especially eggs and females, causing deformations, destruction of ovaries and reducing egg fertility. Also, under acid $\mathrm{pH}$ conditions, it produces toxins that affect the nematode's nervous system (Laverlam 2014).

\section{MYCOTAL $^{\circledR}$ (Koppert 2014) $^{-1}$}

Developed by KOPPERT, Mycotal ${ }^{\circledR}$ contains an entomopathogenic fungus, Verticillium lecanii. It is formulated as a wettable powder. It also acts against the larval stages of whiteflies, with a strong secondary action on adult thrips and red spiders. It has an action on the suppression on $M$. incognita on tomatoes, as reported by Meyer (1999).

\section{TRIANUM $^{\circledR}$ (koppert 2014)}

The use of Trichoderma spp. as biological control agents has been investigated for over 70 years but it is only relatively recently that strains have become commercially available. Many Trichoderma strains, mainly $T$. harzianum, $T$. viride (Masadeh et al. 2004) and T. virens (formerly Gliocladium virens) have been identified as having potential applications in biological control (Lumsden et al. 1993; Monte and Llobell 2001). Trianum ${ }^{\circledR}$ is a product marketed by KOPPERT based on $T$. harzianum T-22. This filamentous fungus has various advantages for the protection of plants and the fight against nematodes (Widden and Abitbol 1980; González et al. 2012): it produces molecules such as 6pentyl $\alpha$-pyrone, VOCs and enzymes (Samson et al. 1996) that can attack the cuticle of nematodes. Also, its hyphae form a physical barrier, which is a difficult step for nematodes, since the fungus grows along with the plant roots. T. harzianum has a beneficial effect on the stimulation of the defense system of the plants (Samuels 1996; Harman 2000).

\section{MET52 $^{\circledR}$ (Novozymes 2014)}

Metarhizium anisopliae is an entomopathogenic fungus used against thrips, termites and mosquitoes. Studies have shown its nematicide potential as well (Mahmoud 2009). The PMRAARLA granted conditional approval in 2010 for the sale and use of $M$. anisopliae strain F52 and the associated end-bio-Met52 Granular Insecticide. Its active ingredient is the F52 strain of $M$. anisopliae in order to remove the root weevils, particularly black vine weevils and strawberry root weevils, which infest ornamental plants grown in pots.

\section{NEMAXXION BIOL ${ }^{\circledR}$ (Greencorp 2014)}

Nemaxxion Biol $^{\circledR}$ has been commercialized by GreenCorp (Mexico). It is a liquid-formulated large-spectra product that is active against nematodes, composed of a consortium of microorganisms (Bacillus subtilis, Trichoderma spp, Paecilomyces spp.) and extracts (tagetes) that are active against RKN.

\section{REM G ${ }^{\circledR}$}

REM $G^{\circledR}$ is a new product commercialized by Green Solutions in Italy. Formulated as a consortium of nematophagous fungi such as Arthrobotrys spp, Dactyllela spp., Paecilomyces spp., Mycorrhiza (Glomus spp.), and bacteria (B. spp. and Pseudomonas spp.), it is supplemented with chitinolytic, proteolytic and lipolytic enzymes to specifically target the nematodes' walls. It is currently showing good results in tomato crops in the Souss-Massa Drâa aera in Morocco (personal information).

\section{PRODUCTION OF BCAs}

There are two ways of producing filamentous fungi (or bacteria, such as Pasteuria penetrans), by Liquid-State Fermentation (LSF) or Solid-State Fermentation (SSF). The choice of the method depends on the desired (liquid or wettable powder) final formulation. It also depends on the strain and on production costs.

\section{PRODUCTION BY LIQUID-STATE FERMENTATION}

Fermentation in a liquid medium is conducted in large, agitated, temperature-controlled and aerated tanks, and is perfectly suited to the production of single-celled organisms such as bacteria or yeasts. Some fungi can be produced by LSF such as Fusarium venenatum, used as Qorn $^{\circledR \text {, for human }}$ food. Examples of microorganisms produced by LSF include $P$. penetrans, $B$. thuringiensis, etc. 


\section{PRODUCTION BY SOLID-STATE FERMENTATION}

SSF is generally known as a culture of microorganisms (preferably filamentous fungi) on a solid substrate without water flow (Hesseltine 1987; Roussos et al. 1993; Mitchell 2002; BarriosGonzález 2012). It exploits the metabolism and growth mechanism of these microorganisms to degrade the solid substrates to produce biopesticides (biomass and secondary metabolites). Microbial growth occurs on the surface and within the solid matrix in the absence of any liquid flow. The porous matrix may be formed from a natural substrate or from an inert support capable of absorbing the nutrients found in dissolved state in a solution. For their mass multiplication, Selvakumar and Srivastava (2000) and Zaidi and Singh (2004), multiplied $T$. harzianum on pre-soaked and autoclaved Jhangora seeds for 12 days at $28^{\circ} \mathrm{C}$, then air-dried, ground and passed them through 50 and 80 mesh sieves simultaneously to obtain spore powder. The commercial formulation was prepared by diluting this powder with talcum powder containing $1 \%$ carboxymethyl-cellulose to get the desirable concentration of biocontrol agent.

\section{FORMULATION OF BCAs}

Formulation is the blending of active ingredients, such as fungal spores, with an inert material, such as diluents or surfactants, in order to preserve the viability and virulence of the strain used. Commercial products also have to present an appropriate structure (powder or liquid) for their application in the field. Formulation must ensure the viability of the strain, preserving its germinating power; it must help the strain keep its virulence against the pest involved. The material can be mineral such as talc (Chaube et al. 2003) or zeolites (Küçük and Kivanç 2005). It is also essential to protect the BCA from the UV rays of the sun and to stabilize the product for both storage and utilization conditions. A granular starch matrix encapsulating B. thuringiensis was patented in 1997 (Quimby et al. 1996). One of the technologies for the formulation of biocontrol organisms is the immobilization of wet or dry biomass within cross-linked polymers such as alginate and carrageen (Cho and Lee 1999). Incorporating fungal mycelia in alginate pellets has been found to be successful for the delivery of biocontrol fungi (Papavizas et al. 1987; Küçük and Kivanç 2005). The biocontrol microorganisms were immobilized, wet or dry, as formulated pellets (Walker and Connick 1983). Alginate-type pellets were used in the formulations of chemical and microbial herbicides (Walker and Connick 1983). In the biotechnology industry, cell entrapment is often used to enhance the production rates of bioproducts, to reduce the mortality of cells, and to facilitate their recovery. Alginate pellets containing the spores of various biocontrol fungi (Lewis and Papavizas 1983; 1985) and of yeast cells have been formulated (Serp et al. 2000). Such preparations offer many advantages compared with the conidial suspensions, e.g., pellets can be stored dry.

\section{CONCLUSION}

Biological control is a sustainable alternative to chemical control. The use of fungi to control the pests like root-knot nematodes may be developed to protect the environment from the pesticides. Unless they are more difficult to produce, store and/or use, they can be a suitable solution to protect the crops. Currently, some products are available on the market and more are being developed. Isolating indigenous strains is the best way to ensure the success of the use of these biological control agents, because they are then adapted to the pest they have to control and to the environment they will be used in. Formulation of these strains should be adapted to ensure both good conservation of the microorganisms and high virulence against the pests.

\section{ACKNOWLEDGMENTS}

This work was supported by IDYL SAS Company and AIRD scientific collaboration (EOTP $\left.\mathrm{N}^{\circ} 4724 \mathrm{~A} 1\right)$.

\section{REFERENCES}

Agrios GN. Plant Pathology. Academic Press, fourth edition. San Diego USA. 1997

Barrios-González J. Solid-state fermentation: Physiology of solid medium, its molecular basis and applications. Process Biochem. 2012; 47: 75-185. 
B'Chir MM. Étude de l'action des champignons prédateurs sur divers nématodes du sol en microscopie électronique à balayage (SEM). Revue Nematol. 1984; 7(1): 29-34.

Bekanayake HMRK, Jayasundar NJ. Effect of Paecilomyces lilacinus and Beauveria bassiana in controlling Meloidogyne incognita on tomato in Sri Lanka. Nematol Medit. 1994; 22: 87-88.

Bélair G. Les nématodes, ces anguillules qui font sur les plantes... par la racine. Phytoprotection. 2005; 86: 6569.

Bird AF. Orientation of the larvae of Meloidogyne javanica relative to roots. Nematol. 1962; 8: 275-287.

Bissadou KD, Tchabi A, Tounou AK, Ayessom A, Gumedzoe M. Impact de la fumure organique appliquée seule et en combinaison avec une souche indigène de champignon mycorhizien arbusculaire Glomus mosseae sur Meloidogyne spp, principal nématode parasitaire de la tomate au Togo. J Appl Biosc. 2012; 55: 3973-3986.

Bradley CA, Black WE, Kearns R, Wood P. Role of production technology in mycoinsecticide development, pp. 160-173. In G. E. Leatham (ed.), Frontiers in industrial microbiology. Chapman \& Hall, New York. 1992

Brand D, Oishi BO, Roussos S, Soccol CR. Spore production of Paecilomyces lilacinus by Solid State Culture and application in Pot Experiments to control Meloidogyne incognita. Appl Biochem Biotech. 2004; 118: 81-88.

Brand D, Soccol CR, Sabu A, Roussos S. Production of fungal biological control agents through solid state fermentation: a case study on Paecilomyces lilacinus against root-knot nematodes. Micol Appl Int. 2009; 21 (2): 33-50.

Bridge J, Plowright RA, Peng D. Nematode parasites of rice. In Plant parasitic nematodes in subtropical and tropical agriculture. 2ond edition. Edited by Luc M., Sikora R.A. and Bridge J. CABI Publishing. 2005.

Caron J, Laverdière L, Venne J, Bélanger R. Recherche et développement de biopesticides et pesticides naturels à faible toxicité pour les organismes non ciblés et respectueux de l'environnement - Rapport final - Volet Phytopathologie. Projet PARDE. 278p. 2006.

Cayrol JC, Dijan C, Pijarowski L. Study of the nematocidal properties of the culture filtrate of the nematophagous fungus Paecilomyces lilacinus. Rev Nematol. 1989; 12 (4): 331-336.

Cayrol JC, Dijan-Caporalino C, Panchaud-Mattei E. La lutte biologique contre les Nématodes phytoparasites. Courrier de la cellule Environnement de l'INRA. 1992; 17: 31-44.

Cayrol JC, Djian C, Frankowski JP. Efficacy of Abamectin B1 for the control of Meloidogyne arenaria. Fund Appl Nematol. 1993; 16: 239-246.

Cayrol JC, Propriétés nématicides des endomycorhizes à vésicules et arbuscules. PHM- Rev Hort. 1991; 321: 3342.

Chaube HS, Mishra S, Varshney DS, Singh SU. Biocontrol of plant pathogens by fungal antagonists: Historical background, present status and future prospects. Ann Rev Pl Pathol. 2003; 2: 1-42.
Chitwood DJ. Research on plant-parasitic nematode biology conducted by the United States Department of Agriculture-Agricultural Research Service. Pest Manag Sci. 2003; 59: 748-753.

Cho CC, Lee WC. Formulation of biocontrol agent by entrapping biomass of Trichoderma viride in gluten matrix. J Biosci Bioengen. 1999; 87 (6) 822-824.

Collange B, Navarrete M, Peyre G, Mateille T, Tchamitchian M. Root-knot nematode (Meloidogyne) management in vegetable crop production: The challenge of an agronomic system analysis. Crop Prot. 2011; 30 (10): 1251-1262.

Davis EL, Hussey R.S, Baum TJ, Bakker J, Schots A, Rosso MN, Abad P. Nematode parasitism genes. Annu Rev Phytopathol. 2000; 38: 365-396.

De Guiran G, Netshter G. Les nématodes du genre Meloidogyne, parasites de cultures tropicales. Cahiers de l'ORSTOM. 1970; 11: 151-185.

DeBach P. Biological control of insect pests and weeds. New York: Reihold. 1964.

Djian-Caporalino C, Védie H, Arrufat A. De nouvelles pistes pour gérer les nématodes à galles. Maraîchage Bio. 2009; 61: 1-6.

Duponnois R, Ba AM, Mateille T. Effects of some rhizosphere bacteria for the biocontrol of nematodes of the genus Meloidogyne with Arthrobotrys oligospora. Fund Appl Nematol.1998; 21 (2): 157-163.

France. Ministère de l'Agriculture, de l'Agroalimentaire et de la Forêt. [cited 2014 sept. 04] Available from: http://agriculture.gouv.fr/

Fravel DR. Commercialization and implementation of biocontrol. Ann Rev Phytopathol. 2005; 43: 337-359.

Gaspard JT, Jaffee BA, Ferris H. Association of Verticillium chlamydosporium and Paecilomyces lilacinus with Root-knot Nematode Infested Soil. J Nematol. 1990; 22 (2): 207-213.

González I, Infante D, Martínez B, Arias Y, González N, Miranda I, Peteira B. Induction of chitinases and glucanases in Trichoderma spp. Strains intended for biological control. Biotecnol Appl. 2012; 29: 12-16.

Goswami BK, Mittal A. Management of root-knot nematode infecting tomato by Trichoderma viride and Paecilomyces lilacinus. Indian Phytopathol. 2004; 57: 235-236.

Goswami BK, Pandey RK, Rathour KS, Bhattacharya C, Singh L. Integrated application of some compatible biocontrol agents along with mustard oil seed cake and furadan on Meloidogyne incognita infecting tomato plants. J Zhejiang Univ Sci. B 2006; 7: 873-875.

Grassé PO. Traité de Zoologie, Anatomie, Systématique, Biologie. Nématodes. Vol. 4, Fasc. $2+3$, Paris: Masson \& Cie. 1965.

Greencorp revolucionamos la agricultura, Nemaxxion Biol. [cited 2014 sept. 04] Available from: http://greencorp.mx/productos.php?id=11\&subcat=2\#pr oductos-Nemaxxion\%20Biol

Hajieghrari B, Torabi-Giglou M, Mohammadi MR., Davari M. Biological potential of some Iranian Trichoderma isolates in control of soil borne plant pathogenic fungi. Afr J Biotechnol. 2008; 7(8): 967-972. 
Harman GE. Changes in perceptions derived from research on Trichoderma harzianum T22. Plant Dis. 2000; 84 (4): 377-393.

Haseeb A, Kumar V. Management of Meloidogyne incognita-Fusarium solani disease complex in brinjal by biological control agents and organic additives. Ann Plant Protect Sci. 2006; 14: 519-521.

Hesseltine CW. Solid state fermentation: an overview. Int Biodeterioration. 1987; 23: 79-89.

Holland RJ, Williams KL, Khan A. Infection of Meloidogyne javanica by Paecilomyces lilacinus. Nematol. 1999; 1: 131-139

Huang XW, Zhao N.H, Zhang KQ. Extracellular enzymes serving as virulence factors in nematophagous fungi involved in infection of the host. Res Microbiol. 2004; 155 (10): 811-816.

Hunt DJ, Handoo ZA. Taxonomy, identification and principal species. In: Perry, RN, Moens M. Starr JL. (Eds.), Root-knot Nematodes. CABI International, Cambridge, MA (USA); 2009.

International Organisation for Biological Control. [cited 2014 sept. 04] Available from: http://www.iobcglobal.org/about_iobc.html

Junaid JM, Dar NA, Bhat TA, Bhat AH, Bhat MA. Commercial Biocontrol Agents and Their Mechanism of Action in the Management of Plant Pathogens. Int $J$ Modern Plant \& Anim Sci. 2013; 1(2): 39-57.

Khan A, Williams KL, Nevalainen HKM. Control of plant-parasitic nematodes by Paecilomyces lilacinus and Monacrosporium lysipagum in pot trials. Biol Control. 2006; 51: 643-658.

Kiewnick S, Sikora RA. Biological control of the root-knot nematode Meloidogyne incognita by Paecilomyces lilacinus strain 251. Biol Control. 2006; 38: 179-187.

Kiewnick S, Sikora RA. Optimizing the efficacy of Paecilomyces lilacinus (strain 251) for the control of root-knot nematodes. Com Appl Biol Sc. 2004; 69: 373380.

Koenning SR, Overstreet C, Noling JW, Donald PA, Becker JO, Fortnum BA. Survey of crop losses in response to phytoparasitic nematodes in the United States for 1994. J Nematol. 1999; 31: 587-618.

Koppert Biological Systems. Mycotal [cited 2014 sept. 04] Available from: http://www.koppert.fr/ravageurs/ thrips/produits-contre-les-thrips/detail/mycotal-4

Koppert Biological Systems. Trianum ${ }^{\circledR}$ [cited 2014 sept. 04] Available from: http://www.koppert.fr/ trianum/

Küçük C, Kivanç M. Effect of formulation on the viability of biocontrol agent, Trichoderma harzianum conidia. Afr J Biotechnol. 2005; 4 (5): 483-486.

Kumar D, Singh KP. Assessment of predacity and efficacy of Arthrobotrys dactyloides for Biological Control of root knot disease of tomato. J Phytopathol. 2006; 154: $1-5$.

Laverlam. Biostat $^{\circledR}$ [cited 2014 sept. 04] Available from: http://www.laverlamintl.com/?page_id=242

Laverlam. BotaniGard ${ }^{\circledR}$ ES [cited 2014 sept. 04] Available from: http://www.laverlamintl.com/?page_id=207

Laverlam. Mycotrol $\mathrm{O}^{\circledR}$ [cited 2014 sept. 04] Available from: http://www.laverlamintl.com/?page_id=91
Lewis JA, Papavizas GC. Characterization of alginate pellets formulated with Trichoderma and Gliocladium and their effect on the proliferation of the fungi in soil. Plant Pathol. 1985; 34: 571-577.

Lewis JA, Papavizas GC. Production of chlamydospore and conidia by Trichoderma spp. liquid and solid growth media. Soil Biol Biochem. 1983; 15: 351-357.

Liu T, Wang L, Duan YX, Wang X. Nematicidal activity of culture filtrate of Beauveria bassiana against Meloidogyne hapla. World J Microbiol Biotechnol. 2008; 24: 113-118.

Lumsden RD, Lewis JA, Locke JC. Managing soilborne plant pathogens with fungal antagonists. In : RD Lumdsen, JL Vaughn, eds. Pest Management : Biologically Based Technologies. Beltsville symp XVIII. Washington, D.C: Am Chem Soc. 1993.

Mahmoud MF. Pathogenicity of Three Commercial Products of Entomopathogenic Fungi, Beauveria bassiana, Metarhizum anisopilae and Lecanicillium lecanii against Adults of Olive Fly, Bactrocera oleae (Gmelin) (Diptera:Tephritidae) in the Laboratory. Plant Protect Sci. 2009; 45 (3): 98-102.

Masadeh B, Von Alten H., Grunewald-Stoecker G., Sikora R.A. Biocontrol of root-knot nematodes using the arbuscular mycorrhizal fungus Glomus intraradices and the antagonist Trichoderma viride in two tomato cultivars differing in their suitability as hosts for the nematodes. J Plant Dis Protect. 2004; 111, 322-333.

Mateille T. Pasteuria penetrans : un nouvel "outil biologique" de lutte contre les nématodes phytoparasites : perspectives d'application en cultures maraîchères. Congad Infos. 1993; (15): 1-2.

Mendoza AR, Sikora RA, Kiewnick S. Influence of Paecilomyces lilacinus 251 on the biological control of the burrowing nematode Radopholus similis in banana. Nematropica 2007; 37 (2): 203-215.

Meyer SLF. Efficacy of the fungus Verticillium lecanii for suppressing root-knot nematode egg numbers on cantaloupe roots. Hort Technology. 1999; 9: 443-447.

Mitchell DA, Berovic M, Krieger N. Overview of solid state bioprocessing. Biotechnol. Ann Rev. 2002; 8: 183225.

Monte E, Llobell A. Trichoderma in organic agriculture. Proceedings V World Avocado Congress (Actas V Congreso Mundial del Aguacate) 2001.

Mukhtar T, Arshad MA, Zameer Kayani M. Biocontrol potential of Pasteuria penetrans, Pochonia chlamydosporia, Paecilomyces lilacinus and Trichoderma harzianum against Meloidogyne incognita in okra. Phytopathol Medit. 2013; 52 (1): 66-76.

Netscher G. Les nématodes parasites des cultures maraîchères au Sénégal. Cahiers de l'ORSTOM. 1970; 11: 209-229.

Novozymes. Met 52, l'insecticide biologique pour le contrôle de l'otiorhynque de la vigne [cited 2014 sept. 04] Available from: http://bioag.novozymes. com/en/products/europe/biocontrol/Documents/Europe_ Met52_fact_sheet_French.pdf

Organic Materials Review Institute. [cited 2014 sept. 04] Available from: http://www.omri.org/ 
Papavizas GC, Fravel DR, Lewis JA. Proliferation of Taleromyces flavus in soil and survival in alginate pellets. Phytopathol.1987; 77: 131-136.

Prophyta. BioAct/Melocon for the control of plant parasitic nematodes [cited 2014 sept. 04] Available from: http://195.98.196.121/en/technology/nematodediseases/

Quimby PC, Birdsall JL, Caesar AJ, Zidack NK, Boyette $\mathrm{CD}$, Connick WJ, Grey WE. Granulated formulation and method for stabilizing biocontrol agents. U.S. Patent Application No. 8,695,249. 1996.

Roussos S, Raimbault M, Prebois JP, Lonsane BK. Zymotis, a large scale solid state fermenter. Appl Biochem Biotech. 1993; 42: 36-52.

Samson RA, Hoekstra ES, Frisvad JC, Filtenborg O. Introduction to food borne fungi. Fifth edition CBS, Netherlands. 1996.

Samuels GJ. Trichoderma: a review of biology and systematics of the genus. Mycol Res. 1996 ; 100: 923935.

Santé Canada. [cited 2014 sept. 04] Available from: http://www.hc-sc.gc.ca/cps-spc/pest/index-fra.php

Sarhy-Bagnon V, Lozano P, Saucedo-Castaneda G, Roussos S. Production of 6-pentyl-alpha-pyrone by Trichoderma harzianum in liquid and solid state cultures. Process Biochem. 2000; 36: 103-109.

Sawadogo A, Diop MT, Thio B, Konate YA, Mateille T. Incidence de quelques facteurs agronomiques sur les populations de Meloidogyne spp. et leurs principaux organismes parasites en culture maraîchère sahélienne. Nematol. 2000; 2 (8): 895-906.

Selvakumar R, Srivastava KD. Management of spot blotch of wheat using bio control agent: National conference on Swadeshi Vighan, held at New Delhi, December 26-28, 2000.

Serp D, Cantana E, Heinzen C, Stockear VU, Marison IW. Characterization of an encapsulation device for the production of monodisperse alginate beads for cell immobilization. Biotechnol Bioengr. 2000; 70: 41-53.

Sharon E, Bar-Eyal M, Chet I, Herrera-Estrella A, Kleifeld O, Spiegel Y. Biological Control of the Root-Knot Nematode Meloidogyne javanica by Trichoderma harzianum. Biol Control. 2001; 91 (7): 687-693.

Siddiqui ZA, Mahmood I. Biological control of plant parasitic nematodes by fungi: a review. Bioresource Technol. 1996; 58: 229-239.
Stirling GR, Licastro KA, West LM, Smith LJ. Development of Commercially Acceptable Formulations of the Nematophagous Fungus Verticillium chlamydosporium. Biol Contr. 1998; 11: 217-223.

Stirling GR, Smith LJ. Field tests of formulated products containing either Verticillium chlamydosporium or Arthrobotrys dactyloides for biological control of rootknot nematodes. Biol Contr. 1998; 11: 229-237.

Stirling GR. "Biological Control of Plant Parasitic Nematodes." CAB International, Wallingford, UK. 1991.

Thakur NSA, Devi G. Management of Meloidogyne incognita attacking okra by nematophagous fungi, Arthrobotrys oligospora and Paecilomyces lilacinus. Agric Sci Dig. 2007; 27: 50-52.

United States Environmental Protection Agency. [cited 2014 sept. 04] Available from: http://www2.epa.gov/ aboutepa/our-mission-and-what-we-do

Van Damme V, Hoedekie A, Viaene N. Long-term efficacy of Pochonia chlamydosporia for management of Meloidogyne javanica in glasshouse crops. Nematology. 2005; 7: 741-745.

Van der Putten WH, Cook R, Costa S, Davies KG, Fargette M, Freitas H, et al. Nematode interactions in nature: models for sustainable control of nematode pests of crop plants? Adv Agron. 2006; 89: 227-260.

Verdejo-Lucas S, Sorribas FJ, Ornat C, Galeano M. Evaluating Pochonia chlamydosporia in a doublecropping system of lettuce and tomato in plastic houses infested with Meloidogyne javanica. Plant Pathol. 2003; 52: 521-528.

Viaene NM, Abawi GS. Management of Meloidogyne hapla on lettuce in organic soil with Sudan grass as a cover crop. Plant Dis. 1998; 82: 945-952.

Walker HL, Connick WJ. Sodium alginate for production and formulation of mycoherbicides. Weed Sci. 1983; 31: 333-338.

Widden P, Abitbol JJ. Seasonality of Trichoderma species in a spruce forest soil. Mycologia. 1980; 72 (4): 775784.

Zaidi WN, Singh US. Development of improved technology for mass multiplication and delivery of fungal (Trichoderma) and bacterial (Pseudomonas) BioControl agents. J Mycol Pl Path. 2004; 34 (3): 732-741.

Received: February 05, 2014; Accepted: September 01, 2014. 